\title{
Replication and meta-analysis of TMEM132D gene variants in panic disorder
}

\author{
A Erhardt ${ }^{1}$, N Akula ${ }^{2}$, J Schumacher ${ }^{3}$, D Czamara ${ }^{1}$, N Karbalai ${ }^{1}$, B Müller-Myhsok ${ }^{1}, 0$ Mors $^{4}$, A Borglum ${ }^{5}$, AS Kristensen ${ }^{4}$, \\ DPD Woldbye $^{6}, \mathrm{P}_{\text {Koefoed }}{ }^{6}$, E Eriksson ${ }^{7}$, E Maron ${ }^{8,24}$, A Metspalu ${ }^{9,10}$, J Nurnberger ${ }^{11}$, RA Philibert ${ }^{12}$, J Kennedy ${ }^{13}$, K Domschke $^{14}$, \\ A Reif ${ }^{14}$, J Deckert ${ }^{14}$, T Otowa ${ }^{15}$, Y Kawamura ${ }^{16}$, H Kaiya ${ }^{17,18}$, Y Okazaki ${ }^{19}$, H Tanii $^{20}$, K Tokunaga $^{21}$, T Sasaki ${ }^{22}$, JPA loannidis ${ }^{23}$, \\ FJ McMahon ${ }^{2}$ and EB Binder ${ }^{1}$
}

\begin{abstract}
A recent genome-wide association study in patients with panic disorder (PD) identified a risk haplotype consisting of two singlenucleotide polymorphisms (SNPs) (rs7309727 and rs11060369) located in intron 3 of TMEM132D to be associated with PD in three independent samples. Now we report a subsequent confirmation study using five additional PD case-control samples $(n=1670$ cases and $n=2266$ controls) assembled as part of the Panic Disorder International Consortium (PanIC) study for a total of 2678 cases and 3262 controls in the analysis. In the new independent samples of European ancestry (EA), the association of rs7309727 and the risk haplotype rs7309727-rs11060369 was, indeed, replicated, with the strongest signal coming from patients with primary PD, that is, patients without major psychiatric comorbidities ( $n=1038$ cases and $n=2411$ controls). This finding was paralleled by the results of the meta-analysis across all samples, in which the risk haplotype and rs7309727 reached $P$-levels of $P=1.4 \mathrm{e}-8$ and $P=1.1 \mathrm{e}-8$, respectively, when restricting the samples to individuals of $E A$ with primary $P D$. In the Japanese sample no associations with PD could be found. The present results support the initial finding that TMEM132D gene contributes to genetic susceptibility for PD in individuals of EA. Our results also indicate that patient ascertainment and genetic background could be important sources of heterogeneity modifying this association signal in different populations.
\end{abstract}

Translational Psychiatry (2012) 2, e156; doi:10.1038/tp.2012.85; published online 4 September 2012

\section{Introduction}

TMEM132D was first identified as a possible candidate gene for panic disorder (PD) in a genome-wide association study conducted at the Max Planck Institute of Psychiatry in Munich. A two single-nucleotide polymorphism (SNP) haplotype in intron 3 of the gene containing the $T$ allele of rs7309727 and the A allele of rs11060369 was highly associated with PD in three German case-control samples, but did not reach genome-wide significance in the metaanalysis. ${ }^{1}$ Furthermore, three independent SNPs located in intron 4 were associated with the severity of anxiety symptoms in patients with a number of different primary psychiatric disorders. Additional evidence for involvement of the TMEM132D gene in anxiety comes from a familybased genome-wide study in patients with ADHD. Here, rs11060369 was highly associated $(P=2.3 e-5)$ with symptoms of anxiety and depression in these patients as measured by the relevant subscales of the Child Behavior Checklist. ${ }^{2}$ Finally, recent data from our group also suggest that private non-synonymous coding mutations in TMEM132D are over-represented in patients with $\mathrm{PD}{ }^{3}$ These findings in humans supporting an involvement of TMEM132D in anxiety are corroborated by data in a mouse model of extremes in trait anxiety that showed a positive correlation of high anxietyrelated behavior and expression of Tmem132d mRNA in the anterior cingulate cortex, as well as association of a Tmem132d SNP with anxiety-related behavior. ${ }^{1}$ The gene expression results in animals are consistent with the finding that the risk allele is correlated with higher TMEM132D expression in the frontal cortex in human postmortem brain tissue. These data would suggest that higher expression of TMEM132D is associated with increased measures of anxiety.

\footnotetext{
${ }^{1}$ Max-Planck-Institute of Psychiatry, Munich, Germany; ${ }^{2}$ Human Genetics Branch, National Institute of Mental Health Intramural Research Program, National Institutes of Health, US Department of Health and Human Services, Bethesda, MD, USA; ${ }^{3}$ Institute for Human Genetics, University of Bonn, Bonn, Germany; ${ }^{4}$ Department of Psychiatry, Aarhus University, Aarhus, Denmark; ${ }^{5}$ Department of Biomedicine, Human Genetics, Aarhus University, Aarhus, Denmark; ${ }^{6}$ Department of Neuroscience and Pharmacology, University of Copenhagen, Copenhagen, Denmark; ${ }^{7}$ University of Gothenburg, Gothenburg, Sweden; ${ }^{8}$ University of Tartu, Tartu, Estonia; ${ }^{9}$ Estonian Biocentre, Tartu, Estonia; ${ }^{10}$ Estonian Genome Center, Institute of Molecular and Cell Biology, University of Tartu, Tartu, Estonia; ${ }^{11}$ Department of Psychiatry, Indiana University, Indianapolis, IN, USA; ${ }^{12}$ Behavioural Genetics, University of lowa, lowa, IA, USA; ${ }^{13}$ University of Toronto, Toronto, Canada; ${ }^{14}$ Department of Psychiatry, University of Würzburg, Würzburg, Germany; ${ }^{15}$ Department of Neuropsychiatry, Graduate School of Medicine, University of Tokyo, Tokyo, Japan; ${ }^{16}$ Research Center for Panic Disorder, Nagoya Mental Clinic, Nagoya, Japan; ${ }^{17}$ Akasaka Mental Clinic, Tokyo, Japan; ${ }^{18}$ Research Center for PanIC Disorder, Nagoya, Japan; ${ }^{19}$ Department of Neurology, Tokyo Metropolitan Matsuzawa Hospital, Tokyo, Japan; ${ }^{20}$ Department of Neuropsychiatry, Graduate School of Medicine, Mie University, Mie, Japan; ${ }^{21}$ Department of Human Genetics, Graduate School of Medicine, University of Tokyo, Tokyo, Japan; ${ }^{22}$ Laboratory of Health Education, Graduate School of Education, University of Tokyo, Tokyo, Japan and ${ }^{23}$ Stanford Prevention Research Center, Departments of Medicine, Health Research and Policy, and Statistics, Stanford University, Stanford, CA, USA

Correspondence: Dr A Erhardt, Max-Planck-Institute of Psychiatry, Kraepelin Street 2-10, Munich 80804, Germany.

E-mail: erhardt @mpipsykl.mpg.de

${ }^{24}$ Current address: Imperial College London, London, UK.

Received 17 July 2012; accepted 23 July 2012
} 
TMEM132D is a single-pass transmembrane protein, which is highly expressed in the cortical regions of the human and mouse brain. The function of the gene product is still unknown. It has been proposed that the protein may serve as a cellsurface marker for oligodendrocyte differentiation. ${ }^{4}$ Other recent data, however, show that it may be most prominently expressed in neurons and colocalizes with actin filaments, ${ }^{5}$ suggesting that TMEM132D may be implicated in neuronal sprouting and connectivity in brain regions important for anxiety-related behavior.

As evidence from multiple studies and experimental approaches point to the putative relevance of TMEM132D in anxiety phenotypes, we wanted to test whether our initial association results could be replicated in independent cohorts for PD. We thus genotyped the top associated TMEM132D SNPs from Erhardt et al. ${ }^{1}$ in five additional PD samples drawn from the Panic Disorder International Consortium (PanIC). ${ }^{6}$ Finally, we performed a meta-analysis including all eight PD samples, three from the initial study and five additionally genotyped samples, for a total of 2678 PD cases and 3262 controls.

\section{Materials and methods}

Samples. The four top associated case-control SNPs in the TMEM132D gene reported in the original study were genotyped in five additional PD samples (total number of PD patients $n=1670$ and controls $n=2266$ ) as part of the PanIC study. ${ }^{6}$ The contributing sites were: (1) Aarhus (cases $n=102$, controls $n=511$ ), Copenhagen (cases $n=141$, controls $n=345$ ) and Gothenburg (cases $n=217$ ) from Denmark and Sweden (ACG); (2) Tartu and Estonia (cases $n=217$, controls $n=285$ ), (3) lowa (cases $n=38$, controls $n=40$ ) and Toronto (cases $n=127$, controls $n=123$ ) from USA/Canada (IT); (4) the National Institute of Mental Health (NIMH), USA (cases $n=77$, controls $n=192$ ); and (5) Japan (cases $n=760$, controls $n=760$ ) (Table 1). Subjects were matched for gender and age and must have had their first panic attack before developing an alcohol abuse disorder and before the age of 35 .

In the final meta-analysis, eight PD samples were included; three German samples are described in Erhardt et al. ${ }^{1}$ (MPI (discovery sample): recruited at the Max Planck Institute in Munich; PD German multicenter (Stage 2): recruited at Universities of Münster, Würzburg, Bonn and Göttingen; Bonn (Stage 3): recruited at the University of Bonn). All patients in the eight PD samples had a DSM-IV or ICD-10 (Aarhus, MPI ${ }^{1}$ ) based diagnosis of PD, with or without agoraphobia. Information regarding the recruitment and characterization of cases and controls is detailed in these references. ${ }^{7-14}$ In most samples, PD was the primary diagnosis (ACG, Tartu, Toronto, Japan, $\mathrm{MPI}^{1}$ and PD German multicenter ${ }^{1}$ ), except for the cases from lowa, the NIMH and Bonn. Cases and controls

Table 1 Demographic data of eight PD samples included in the final meta-analysis

\begin{tabular}{|c|c|c|c|c|c|c|}
\hline \multirow[t]{2}{*}{ Sample } & \multicolumn{2}{|c|}{ Number } & \multicolumn{2}{|c|}{ Gender } & \multirow{2}{*}{$\begin{array}{l}\text { PD diagnosis } \\
\text { Cases }\end{array}$} & \multirow{2}{*}{$\begin{array}{l}\text { Comorbidity } \\
\text { Cases }\end{array}$} \\
\hline & Cases & Controls & Cases & Controls & & \\
\hline $\begin{array}{l}\text { ACG total } \\
\text { Aarhus } \\
\text { Copenhagen } \\
\text { Gothenburg }\end{array}$ & $\begin{array}{l}460 \\
102 \\
141 \\
217\end{array}$ & $\begin{array}{r}856 \\
511 \\
345 \\
0\end{array}$ & $\begin{array}{l}\text { Male } 25.0 \% \\
\text { Female } 75.0 \%\end{array}$ & $\begin{array}{l}\text { Male } 50.5 \% \\
\text { Female } 49.5 \%\end{array}$ & $\begin{array}{l}\text { PDA } 56 \%, \text { PD } 44 \% \\
\text { PPD } 77.6 \%\end{array}$ & $\begin{array}{l}\text { MDE } 22.2 \% \\
\text { SA } 5.2 \% \\
\text { NS } 47.1 \%\end{array}$ \\
\hline Tartu & 217 & 285 & $\begin{array}{l}\text { Male } 23.0 \% \\
\text { Female } 77.0 \%\end{array}$ & $\begin{array}{l}\text { Male } 30.0 \% \\
\text { Female } 70.0 \%\end{array}$ & $\begin{array}{l}\text { PDA } 61.5 \% \text {, PD } 38.5 \% \\
\text { PPD } 49.7\end{array}$ & $\begin{array}{l}\text { MDE/BP } 62.3 \% \\
\text { SA } 15.6 \%\end{array}$ \\
\hline $\begin{array}{l}\text { IT total } \\
\text { Iowa } \\
\text { Toronto }\end{array}$ & $\begin{array}{r}165 \\
38 \\
127\end{array}$ & $\begin{array}{r}163 \\
40 \\
123\end{array}$ & $\begin{array}{l}\text { Male } 29.7 \% \\
\text { Female } 70.3 \%\end{array}$ & $\begin{array}{l}\text { Male } 26 \% \\
\text { Female } 74 \%\end{array}$ & $\begin{array}{l}\text { PDA } 75.6 \% \text {, PD } 24.4 \% \\
\text { PPD } 60.6 \%\end{array}$ & MDE/BP 39.9\% \\
\hline $\mathrm{NIMH}$ & 77 & 192 & $\begin{array}{l}\text { Male } 21.0 \% \\
\text { Female } 79.0 \%\end{array}$ & $\begin{array}{l}\text { Male } 21.0 \% \\
\text { Female } 79.0 \%\end{array}$ & $\begin{array}{l}\text { PDA } 38.8 \% \text {, PD } 61.2 \% \\
\text { PPD } 0 \%\end{array}$ & MDE/BP $100 \%$ \\
\hline Japan & 760 & 770 & $\begin{array}{l}\text { Male } 31.8 \% \\
\text { Female } 68.2 \%\end{array}$ & $\begin{array}{l}\text { Male } 52.8 \% \\
\text { Female } 47.2 \%\end{array}$ & $\begin{array}{l}\text { PDA } 57.3 \%, \text { PD } 42.7 \% \\
\text { PPD } 35.8 \%\end{array}$ & $\begin{array}{l}\text { MDE } 42.8 \% \text {, SA } 5.2 \% \text {, } \\
\text { OAD } 4.0 \% \text {, OCD } 3.3 \%\end{array}$ \\
\hline $\mathrm{MPI}^{\mathrm{a}}$ & 216 & 222 & $\begin{array}{l}\text { Male } 33.2 \% \\
\text { Female } 66.8 \%\end{array}$ & $\begin{array}{l}\text { Male } 32.9 \% \\
\text { Female } 67.1 \%\end{array}$ & $\begin{array}{l}\text { PDA 83.3\%, PD } \\
16.7 \% \text { PPD } 100 \%\end{array}$ & - \\
\hline PD German multicenter ${ }^{a}$ & 225 & 240 & $\begin{array}{l}\text { Male } 40.4 \% \\
\text { Female } 59.6 \%\end{array}$ & $\begin{array}{l}\text { Male } 40.2 \% \\
\text { Female } 59.8 \%\end{array}$ & $\begin{array}{l}\text { PDA } 67.5 \%, \text { PD } \\
32.5 \% \text { PPD } 78.2 \%\end{array}$ & $\begin{array}{l}\text { MDE } 22.7 \% \\
\text { SA } 8.9 \%, \text { NS } 25.3 \%\end{array}$ \\
\hline Bonn $^{a}$ & 436 & 452 & $\begin{array}{l}\text { Male } 33.3 \% \\
\text { Female } 66.7 \%\end{array}$ & $\begin{array}{l}\text { Male } 50.9 \% \\
\text { Female } 49.1 \%\end{array}$ & $\begin{array}{l}\text { PDA } 39 \% \text {, PD } 20.4 \% \\
\text { PPD } 10.1 \%\end{array}$ & $\begin{array}{l}\text { MDE/BP } 73.4 \% \text {, OAD } 40.6 \% \\
\text { SchiD } 10.6 \%\end{array}$ \\
\hline
\end{tabular}

Abbreviations: ACG, Aarhus, Copenhagen (Denmark), Gothenburg (Sweden); BP, bipolar disorder; IT, lowa, Toronto (USA, Canada); MDE, depressive disorder; MPI, Max Planck Institute for Psychiatry, Munich; NIMH, National Institute for Mental Health (USA); NS, not specified; OAD, other anxiety disorders; PDA, panic disorder with agoraphobia; PD, panic disorder without agoraphobia; PD German multicenter, recruited in Münster, Würzburg, Göttingen and Bonn; PPD, primary PD, exclusion of severe and recurrent major depression, bipolar disorder, schizophrenia and substance dependence; SA, substance abuse or dependence secondary to the panic disorder (mainly alcoholism); SchiD, schizophrenic disorder.

Patients and controls were matched by age; mean age of all patients 39.1 (s.d. 11.5); mean age controls 39.4 (s.d. 11.9).

aPD samples previously genotyped in Erhardt et al. 
Table 2 Single-SNP association analysis, haplotype analysis and meta-analysis results of the five newly genotyped samples from the PanIC

\begin{tabular}{|c|c|c|c|c|c|c|}
\hline Samples & $A C G$ & Tartu & $I T$ & $N I M H$ & Japan & Combined \\
\hline $\begin{array}{l}\text { Number of cases } \\
\text { Number of controls }\end{array}$ & $\begin{array}{l}460 \\
856\end{array}$ & $\begin{array}{l}217 \\
285\end{array}$ & $\begin{array}{l}165 \\
163\end{array}$ & $\begin{array}{r}77 \\
192\end{array}$ & $\begin{array}{l}760 \\
770\end{array}$ & $\begin{array}{l}1679 \\
2266\end{array}$ \\
\hline \multicolumn{7}{|l|}{$\begin{array}{l}\text { SNPs } \\
\quad \text { rs7309727 }\end{array}$} \\
\hline $\begin{array}{l}P \text {-value } \\
\text { OR }(\mathrm{Cl})\end{array}$ & $\begin{array}{c}0.001 \\
1.36(1.13-1.65)\end{array}$ & $\begin{array}{c}0.5 \\
1.09(0.82-1.47)\end{array}$ & $0.95(0.66-1.36)$ & $\begin{array}{c}0.05 \\
0.63(0.39-1.0)\end{array}$ & $\begin{array}{c}0.4 \\
0.94(0.81-1.09)\end{array}$ & $1.04(0.93-1.16)$ \\
\hline $\begin{array}{c}\text { rs11060369 } \\
P \text {-value } \\
\text { OR }(\mathrm{Cl})\end{array}$ & $\begin{array}{c}0.9 \\
0.99(0.83-1.18)\end{array}$ & $\begin{array}{c}0.6 \\
0.92(0.7-1.21)\end{array}$ & $\begin{array}{c}\mathbf{0 . 0 1} \\
0.67(0.49-0.94)\end{array}$ & $\begin{array}{c}0.6 \\
0.90(0.61-1.32)\end{array}$ & $\begin{array}{c}0.8 \\
0.98(0.85-1.14)\end{array}$ & $\begin{array}{c}0.28 \\
0.94(0.87-1.04)\end{array}$ \\
\hline $\begin{array}{c}\text { rs9804847 } \\
P \text {-value } \\
\text { OR }(\mathrm{Cl})\end{array}$ & $\begin{array}{c}0.9 \\
1.0(0.85-1.18)\end{array}$ & $\begin{array}{c}0.3 \\
1.15(0.88-1.49)\end{array}$ & $\begin{array}{c}0.05 \\
0.72(0.52-1.01)\end{array}$ & $\begin{array}{c}0.17 \\
0.77(0.53-1.11)\end{array}$ & $\begin{array}{c}0.2 \\
1.21(0.93-1.58)\end{array}$ & $\begin{array}{c}0.97 \\
0.99(0.89-1.11)\end{array}$ \\
\hline $\begin{array}{c}\text { rs4759958 } \\
P \text {-value } \\
\text { OR }(\mathrm{Cl})\end{array}$ & $\begin{array}{c}0.07 \\
1.17(0.98-1.38)\end{array}$ & $0.96(0.73-1.28)$ & $\begin{array}{c}0.1 \\
0.28(0.93-1.75)\end{array}$ & $\begin{array}{c}0.7 \\
1.07(0.73-1.60\end{array}$ & $1.07(0.93-1.24)$ & $\begin{array}{c}0.036 \\
1.11(1.0-1.23)\end{array}$ \\
\hline \multicolumn{7}{|c|}{ Haplotype rs7309727-rs11060369 } \\
\hline Omnibus test & 0.0054 & 0.81 & 0.21 & 0.037 & 0.33 & 0.47 \\
\hline $\begin{array}{l}\text { CC } \\
P \text {-value } \\
\text { OR }(\mathrm{Cl})\end{array}$ & $\begin{array}{c}0.69 \\
0.98(0.82-1.17)\end{array}$ & $\begin{array}{c}0.54 \\
0.92(0.70-1.21)\end{array}$ & $0.67(0.49-0.94)$ & $\begin{array}{c}0.51 \\
0.99(0.82-1.17)\end{array}$ & $0.98(0.81-1.1)$ & $\begin{array}{c}0.77 \\
0.99(0.90-1.08)\end{array}$ \\
\hline $\begin{array}{l}\text { TA } \\
P \text {-value } \\
\text { OR }(\mathrm{Cl})\end{array}$ & $\begin{array}{c}\mathbf{0 . 0 0 2 3} \\
1.36(1.12-1.65)\end{array}$ & $\begin{array}{c}0.5 \\
1.1(0.81-1.49)\end{array}$ & $\begin{array}{c}0.7 \\
0.95(0.66-0.37)\end{array}$ & $\begin{array}{c}0.057 \\
0.63(0.4-1.0)\end{array}$ & $\begin{array}{c}0.37 \\
0.93(0.81-1.08)\end{array}$ & $\begin{array}{c}0.036 \\
1.11(0.10-1.24)\end{array}$ \\
\hline $\begin{array}{l}\text { CA } \\
P \text {-value } \\
\text { OR }(\mathrm{Cl})\end{array}$ & $\begin{array}{c}\mathbf{0 . 0 0 6} \\
0.79(0.67-0.93)\end{array}$ & $\begin{array}{c}0.9 \\
1.0(0.99-1.01)\end{array}$ & $\begin{array}{c}0.01 \\
1.5(1.1-2.05)\end{array}$ & $\begin{array}{c}\mathbf{0 . 0 1 7} \\
1.6(1.1-2.39)\end{array}$ & $\begin{array}{c}0.16 \\
1.15(0.95-1.39)\end{array}$ & $\begin{array}{c}0.064 \\
0.91(0.84-1.0)\end{array}$ \\
\hline
\end{tabular}

Abbreviations: ACG, Aarhus, Copenhagen, Gothenburg; CI, 95\% confidence interval; EA, European ancestry,all samples except the Japanese sample; IT, lowa, Toronto (USA, Canada); NIMH, National Institute for Mental Health (USA); OR, odds ratio; PanIC, Panic Disorder International Consortium; SNP, single-nucleotide polymorphism.

Nominally significant $P$-values are displayed in bold digits.

from lowa were recruited from a large longitudinal case and control adoption study of substance use. The samples from Bonn and NIMH were primarily recruited from families with bipolar disorder (Table 1). In the primary PD samples listed above, control individuals were recruited from the general population. The presence of $\mathrm{PD}$ and other psychiatric disorders was excluded by administering either a short questionnaire (Japan, ACG) or a structural interview (MPI: SCID, Toronto: Mini-SCID, Tartu: MINI). All studies were approved by the local ethical committees.

Genotyping. The genotyping was performed at the NIMH. For genotyping, pre-designed TaqMan SNP assays were used according to the manufacturer's protocol on the MJ Research Tetrad PTC-225 Thermo Cycler (Bio-Rad Laboratories, Hercules, CA, USA) and intensities were read on an Analyst HT fluorescent plate reader (Molecular Devices, Sunnyvale, CA, USA). The genotypes were scored using a clustering algorithm kindly provided by Sam Chen, Virginia Commonwealth University (Richmond, VA, USA).

Statistics. Case-control association analyses were conducted using PLINK (http://pngu.mgh.harvard.edu/ purcell/ plink/) with an additive model for the single-SNP associations and the option hap-logistic for haplotype-based associations.
$P \leqslant 0.05$ were considered as nominally significant. Fixedeffects meta-analysis and forest plots were assessed with the R-library rmeta (http://www.r-project.org/). We first analyzed the newly genotyped five PD samples for singleSNP association and haplotype association ( $n=1679$ cases, $n=2266$ controls). In the second step, a meta-analysis of these five samples was performed. Finally, a meta-analysis of all eight available PD samples, including the first three samples reported in Erhardt et al. (combined: cases $n=2678$, controls $n=3262$ ), was done, followed by metaanalyses restricted to European ancestry (EA) samples, only excluding the Japanese sample (EA: $n=1863$ cases, $n=2411$ controls). As the association of TMEM132D variants in the original publication was highest for PD without major comorbidities, we further stratified the EA samples by primary diagnosis of PD (PPD; cases $n=1038$, controls $n=2411$ ), that is, excluding all patients with comorbid major depression, bipolar disorders, schizophrenia or substance dependence.

\section{Results}

Independent replication samples. Single-SNP analysis and haplotype analysis of the five newly genotyped samples 
are presented in Table 2. Single-SNP associations in the same direction as in the initial three German samples were seen in the ACG sample and partly in the sample from IT for the top two SNPs, rs7309727 and rs11060369, being strongest in the ACG sample (for example, rs7309727, $P=0.001)$. The analysis of the haplotype rs7309727rs11060369 was nominally significant in the omnibus test in the ACG $(P=0.0054)$ and $\operatorname{NIMH~}(P=0.037)$ samples. The single-risk haplotype TA reported in the original study could be replicated with nominally significant results only in the ACG sample $(P=0.0023)$. In the meta-analysis of the five new PD samples, nominally significant results could be obtained only for rs4759958 $(P=0.036)$. Nominally significant associations in the same direction as in the first report were observed for rs7309727 for EA populations $(P=0.045)$ and PPD $(P=0.003)$, but not in the combined analysis $(P=0.28)$. The meta-analysis of the haplotype rs7309727rs11060369 was not nominally significant using the omnibus test. However, the meta-analysis for the risk haplotype TA reached nominal significance $(P=0.036)$ with a trend for the protective haplotype $\mathrm{CA}(P=0.06)$, both with congruent directions to the first study.

Meta-analysis across all samples. The results of the final meta-analysis including eight PD samples for single SNPs and haplotype rs7309727-rs11060369 are summarized in Table 3.

In the meta-analysis of all EA samples with primary PD, the association with rs7309727 was strongest $(P=1.8 \mathrm{e}-8$, $\mathrm{OR}=1.43$ ) (Figure 1). Associations were less significant when analyzing all EA samples $(P=2.5 e-6)$ or all samples together, including the Japanese sample $(P=0.0007)$. When the meta-analysis was further restricted to primary PD samples recruited at European sites (cases $n=908$, controls $n=2056)$, the significance increased to a $P$-value of $7.1 \mathrm{e}-9$ (OR 1.48). Similar results were obtained for the risk haplotype TA for rs7309727-rs11060369 (EA PPD $P=1.4$ e -8 , OR 1.44; see Figure 2 and Table 3 ). It is noteworthy that the association of the protective haplotype $\mathrm{CC}$ is strengthened in all combined samples, especially in the EA sample, and that this haplotype is associated in the same direction with PD in all eight samples.

\section{Discussion}

The present results support the association of rs7309727 and the risk haplotype rs7309727-rs11060369 in the TMEM132D gene in EA samples selected for PPD, corroborating the initial finding that TMEM132D gene contributes to the genetic susceptibility for PD.

In fact, the association of rs7309727 and the risk haplotype rs7309727-rs11060369 replicates in the new independent samples of European descent, with the strongest signal coming from patients with primary PD (see Table 2). This was paralleled by the findings from the meta-analysis across all samples in which the association reached a significance level below the threshold for multiple correction for genome-wide association studies in this subgroup of patients (see Table 3). This indicates that the association with the TMEM132D is

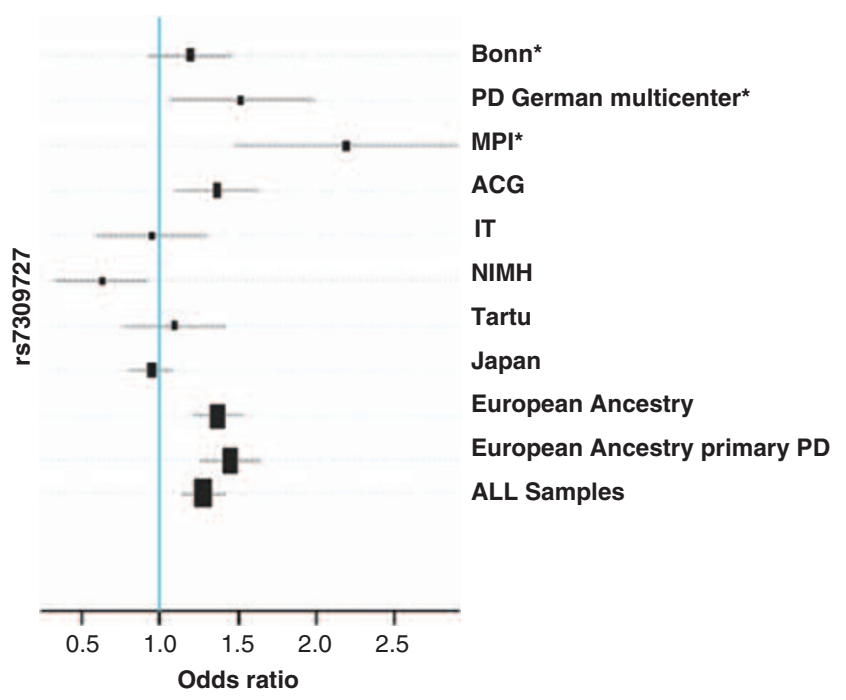

Figure 1 Combined meta-analysis for the SNP rs7309727 in the TMEM132D gene. ACG: Aarhus, Copenhagen, Gothenburg; Tartu (Estonia); European Ancestry: all samples except the Japanese sample; European Ancestry primary PD: exclusion of cases with severe and recurrent major depression, bipolar disorder, schizophrenia and substance dependence; IT: lowa, Toronto (USA, Canada); MPI: Max Planck Institute for Psychiatry, Munich; NIMH: National Institute for Mental Health (USA). *Samples published in Erhardt et al. ${ }^{1}$

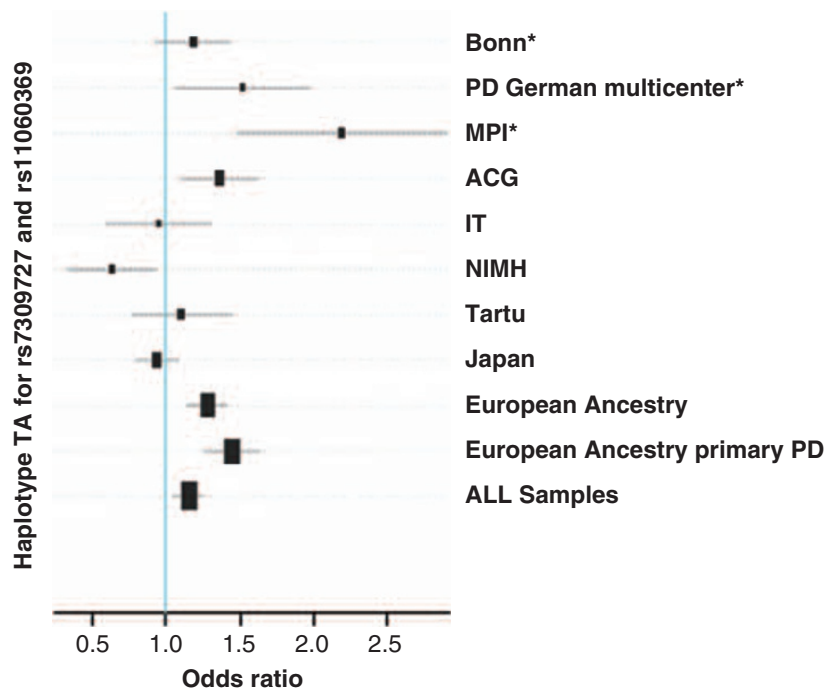

Figure 2 Combined meta-analysis of the risk haplotype TA for rs7309727 and rs11060369. ACG: Aarhus, Copenhagen, Gothenburg; Tartu (Estonia); European Ancestry: all samples except the Japanese sample; European Ancestry primary PD: exclusion of cases with severe and recurrent major depression, bipolar disorder, schizophrenia and substance dependence; IT: lowa, Toronto (USA, Canada); MPI: Max Planck Institute for Psychiatry, Munich; NIMH National Institute for Mental Health (USA). *Samples published in Erhardt et al. ${ }^{1}$

strongest when increasing the homogeneity of the samples with respect to both genetic background as well as case ascertainment and/or definition strategies.

The association was not replicated in the studied Japanese sample, perhaps due to differences in risk alleles or population structure. Consistent with this idea, the tests 
Table 3 Meta-analysis results for eight PD samples (PanIC: $n=5$; Erhardt et al:: $n=3$ ) for the top SNPs and the best associated haplotype rs7309727-rs11060369 in the TMEM132D gene

\begin{tabular}{|c|c|c|c|c|}
\hline Samples & Combined & European ancestry & European ancestry PPD & Japan PPD \\
\hline $\begin{array}{l}\text { Number of cases } \\
\text { Number of controls }\end{array}$ & $\begin{array}{l}2678 \\
3262\end{array}$ & $\begin{array}{l}1863 \\
2411\end{array}$ & $\begin{array}{l}1038 \\
2411\end{array}$ & $\begin{array}{l}760 \\
770\end{array}$ \\
\hline $\begin{array}{l}\text { SNPS } \\
\text { rs7309727 } \\
\text { P-value } \\
\text { OR }(\mathrm{Cl}) \\
\text { p-het }\end{array}$ & $\begin{array}{c}0.0007 \\
1.16(1.05-1.26) \\
5.97 e-6\end{array}$ & $\begin{array}{c}3.98 e-6 \\
1.27(1.15-1.41) \\
0.0003\end{array}$ & $\begin{array}{c}1.05 e-8 \\
1.45(1.20-1.72) \\
\text { NS }\end{array}$ & $\begin{array}{c}0.27 \\
0.90(0.73-1.09)\end{array}$ \\
\hline $\begin{array}{l}\text { rs11060369 } \\
P \text {-value } \\
\text { OR }(\mathrm{Cl}) \\
\text { p-het }\end{array}$ & $\begin{array}{c}0.0007 \\
0.87(0.74-0.94) \\
0.01\end{array}$ & $\begin{array}{c}7.64 \mathrm{e}-5 \\
0.83(0.75-0.90) \\
0.034\end{array}$ & $\begin{array}{c}0.0004 \\
0.81(0.73-0.89) \\
\text { NS }\end{array}$ & $\begin{array}{c}0.78 \\
0.97(0.80-1.18)\end{array}$ \\
\hline $\begin{array}{c}\text { rs9804847 } \\
\text { P-value } \\
\text { OR (Cl) } \\
\text { p-het }\end{array}$ & $\begin{array}{c}0.05 \\
1.08(1.0-1.18) \\
0.009\end{array}$ & $\begin{array}{c}0.1 \\
1.07(0.98-1.17) \\
0.006\end{array}$ & $\begin{array}{c}0.12 \\
1.09(0.96-1.22) \\
0.005\end{array}$ & $\begin{array}{c}0.16 \\
1.29(0.90-1.84)\end{array}$ \\
\hline $\begin{array}{c}\text { rs4759958 } \\
\text { P-value } \\
\text { OR (Cl) } \\
\text { p-het }\end{array}$ & $\begin{array}{c}0.003 \\
1.12(1.1-1.21) \\
\text { NS }\end{array}$ & $\begin{array}{c}0.006 \\
1.14(1.05-1.26) \\
\text { NS }\end{array}$ & $\begin{array}{c}0.06 \\
1.11(0.97-1.26) \\
\text { NS }\end{array}$ & $\begin{array}{c}0.08 \\
1.20(0.98-1.47)\end{array}$ \\
\hline Haplotype rs73097 & 369 & & & \\
\hline $\begin{array}{l}\text { Omnibus test } \\
\text { CC } \\
\text { P-value } \\
\text { OR }(\mathrm{Cl}) \\
\text { p-het }\end{array}$ & $\begin{array}{c}0.00014 \\
0.0003 \\
0.87(0.8-0.93) \\
0.02\end{array}$ & $\begin{array}{c}1.12 e-6 \\
3.8 e-5 \\
0.82(0.75-0.90) \\
0.022\end{array}$ & $\begin{array}{c}\mathbf{5 . 0 2 e}-\mathbf{8} \\
0.0004 \\
0.80(0.73-0.89) \\
\text { NS }\end{array}$ & $\begin{array}{c}0.13 \\
0.73 \\
0.96(0.80-1.17)\end{array}$ \\
\hline $\begin{array}{l}\text { TA } \\
\text { P-value } \\
\text { OR }(\mathrm{Cl}) \\
\text { p-het }\end{array}$ & $\begin{array}{c}0.001 \\
1.15(1.06-1.25) \\
9.4 e-6\end{array}$ & $\begin{array}{c}3.35 e-6 \\
1.28(1.15-1.41) \\
0.0002\end{array}$ & $\begin{array}{c}1.4 \mathbf{e}-\mathbf{8} \\
1.44(1.20-1.73) \\
\text { NS }\end{array}$ & $\begin{array}{c}0.24 \\
0.89(0.74-1.06)\end{array}$ \\
\hline $\begin{array}{l}\text { CA } \\
P \text {-value } \\
\text { OR }(\mathrm{Cl}) \\
\text { p-het }\end{array}$ & $\begin{array}{c}0.9 \\
1.0(0.99-1.01) \\
9.6 e-4\end{array}$ & $\begin{array}{c}0.9 \\
1.0(0.99-1.01) \\
0.001\end{array}$ & $\begin{array}{c}0.09 \\
0.91(0.82-1.0) \\
\text { NS }\end{array}$ & $\begin{array}{c}0.17 \\
1.3(0.92-1.83)\end{array}$ \\
\hline
\end{tabular}

Abbreviations: ACG. Aarhus, Copenhagen, Gothenburg; $\mathrm{Cl}, 95 \%$ confidence interval; Combined, all eight PD samples including the initial German samples from Munich, PD German multicenter and Bonn; European ancestry, all samples except the Japanese sample; IT, Iowa, Toronto (USA, Canada); NIMH, National Institute for Mental Health (USA); NS, not significant; OR, odds ratio; $p$-het, $P$-value test for heterogeneity; PanIC, Panic Disorder International Consortium; PPD, primary panic disorder, exclusion of cases with severe and recurrent major depression, bipolar disorders, schizophrenia and substance dependence; SNP, single-nucleotide polymorphism.

Results for the combined meta-analysis and subsamples. $P$-values surviving correction for multiple testing genome-wide are displayed in bold.

of heterogeneity were significant in the combined sample, whereas they were not significant for the meta-analysis of the EA and European PPD samples. The differences in genetic background between the Asian and the European samples may contribute to this heterogeneity, as the functional variant underlying the association signal in intron 3 has not yet been identified. Further finemapping of the locus in both samples will be necessary to address this issue. Promising preliminary findings come from a GWAS for PD in a Japanese population, in which two SNPs in the TMEM132D gene located in the same intron as the top SNPs in the present study showed nominal association with PD. ${ }^{15}$ This may suggest that a common but yet unidentified functional variant underlies the signals found in the EA and Japanese populations. It is increasingly recognized that significant differences in associations obtained from GWAS in different ancestry groups are not uncommon. ${ }^{16}$

An interesting aspect of this study is that TMEM132D variants showed the strongest associations when restricting the European descent samples to patients with primary PD. While this is in line with our previous report, in which these variants were associated with PD but not with the dimensional measure of anxiety, it is at odds with a recent report that rs11060369 is associated with dimensional measures of anxiety in patients with $\mathrm{ADHD} .^{2}$ In a recent pooled genomewide association study in German individuals with personality disorders, one SNP in TMEM132D located in the intron 4 was nominally associated with Cluster B and C Personality Disorders (Weißflog et al., in revision). We had previously reported associations with dimensional measures of anxiety with a set of linked variants in intron 4 of TMEM132D that are not in linkage disequilibrium with the disease-associated variants in intron 3 . In fact, these associations with dimensional anxiety measures were seen in patients with anxiety disorders, major depression as well as healthy individuals. ${ }^{1}$ Additional studies investigating different or common loci in TMEM132D associated with PD specifically or dimensional anxiety measures will be necessary. 
This study presents genetic association data in the largest collection of patients with PD published to date (cases $n=2678$, controls $n=3262$ ), within the PanIC consortium. While we observe interesting supportive data for the association of TMEM132D with primary PD in individuals of European ancestry, additional studies in larger samples with an increased marker density are needed to identify the possible sources of heterogeneity of the observed association, and seek further replication and extensions of our findings in samples of different ethnic backgrounds, and to identify the putative functional variants.

\section{Conflict of Interest}

The authors declare no conflict of interest.

Acknowledgements. We thank all the collaborators from the initial study to TMEM132D for their excellent contributions, especially Marcella Rietschel, Markus Noethen, Sven Cichon, Borwin Bandelow, Wolfgang Meier, Ludwig Czibere and Rainer Landgraf. We thank the support by the NIMH Intramural Research Program (FJM, NA, JS), and the grant support to Andreas Reif, Jürgen Deckert and Katharina Domschke by the Deutsche Forschungsgemeinschaft, SFB-TRR-58, projects $\mathrm{C} 2$ and $\mathrm{Z} 2$.

1. Erhardt A, Czibere L, Roeske D, Lucae S, Unschuld PG, Ripke S et al. TMEM132D, a new candidate for anxiety phenotypes: evidence from human and mouse studies. Mol Psychiatry 2011; 16: 647-663.

2. Mick E, McGough J, Loo S, Doyle AE, Wozniak J, Wilens TE et al. Genome-wide association study of the child behavior checklist dysregulation profile. J Am Acad Child Adolesc Psychiatry 2011; 50: 807-817.

3. Quast C, Altmann A, Weber P, Arloth J, Bader D, Heck A et al. Rare variants in TMEM132D in a case-control sample for panic disorder. Am J Med Genet Part B 2012; 1-12 (e-pub ahead of print).
4. Nomoto $\mathrm{H}$, Yonezawa T, Itoh K, Ono K, Yamamoto K, Oohashi T et al. Molecular cloning of a novel transmembrane protein MOLT expressed by mature oligodendrocytes. J Biochem 2003; 134: 231-238.

5. Walser SM, Dedic N, Touma C, Floss T, Wurst W, Holsboer F et al. TMEM132D-a putative cell adhesion molecule involved in panic disorder. Pharmacopsychiatry 2011; 44.

6. Schumacher J, Kristensen AS, Wendland JR, Nothen MM, Mors O, McMahon FJ. The genetics of panic disorder. J Med Genet 2011; 48: 361-368.

7. Gregersen N, Dahl HA, Buttenschon HN, Nyegaard M, Hedemand A, Als TD et al. A genome-wide study of panic disorder suggests the amiloride-sensitive cation channel 1 as a candidate gene. Eur J Hum Genet 2012; 20: 84-90.

8. Koefoed P, Woldbye DP, Hansen TO, Hansen ES, Knudsen GM, Bolwig TG et al. Gene variations in the cholecystokinin system in patients with panic disorder. Psychiatr Genet 2010; 20: 59-64.

9. Annerbrink K, Westberg L, Olsson M, Andersch S, Sjodin I, Holm G et al. Panic disorder is associated with the Val308lso polymorphism in the hypocretin receptor gene. Psychiatr Genet 2011; 21: 85-89.

10. Maron E, Nikopensius T, Koks S, Altmae S, Heinaste E, Vabrit K et al. Association study of 90 candidate gene polymorphisms in panic disorder. Psychiatr Genet 2005; 15: 17-24.

11. Philibert R. Merging genetic and environmental effects in the lowa Adoption Studies: focus on depression. Ann Clin Psychiatry 2006; 18: 219-222.

12. Rothe C, Koszycki D, Bradwejn J, King N, Deluca V, Tharmalingam S et al. Association of the Val158Met catechol O-methyltransferase genetic polymorphism with panic disorder. Neuropsychopharmacology 2006; 31: 2237-2242.

13. Smith EN, Bloss CS, Badner JA, Barrett T, Belmonte PL, Berrettini W et al. Genome-wide association study of bipolar disorder in European American and African American individuals. Mol Psychiatry 2009; 14: 755-763.

14. Otowa T, Tanii H, Sugaya N, Yoshida E, Inoue K, Yasuda S et al. Replication of a genome-wide association study of panic disorder in a Japanese population. J Hum Genet 2010; 55: 91-96.

15. Otowa T, Yoshida E, Sugaya N, Yasuda S, Nishimura Y, Inoue K et al. Genome-wide association study of panic disorder in the Japanese population. J Hum Genet 2009; 54: $122-126$.

16. Ntzani EE, Liberopoulos G, Manolio TA, loannidis JP. Consistency of genome-wide associations across major ancestral groups. Hum Genet 2012; 131: 1057-1071.

Translational Psychiatry is an open-access journal published by Nature Publishing Group. This work is licensed under the Creative Commons Attribution-NonCommercial-No Derivative Works 3.0 Unported License. To view a copy of this license, visit http://creativecommons.org/licenses/by-nc-nd/3.0/ 